\title{
The Quest for the Whole in D. H. Lawrence's Sons and Lovers
}

\author{
Nesar Uddin \\ Dept. of English Language and Literature \\ International Islamic University Chittagong, Dhaka Campus \\ 147/1 Green Road, Dhaka 1205
}

Received: 28-08 - 2013

doi:10.7575/aiac.ijclts.v.1n.3p.35
Accepted: 30-09- 2013

Published: 15-10- 2013

\begin{abstract}
David Herbert Lawrence portrays a complex husband-wife, mother-son, and man-woman relationship in his novel Sons and Lovers. This article studied the relational motifs of the major character Paul Morel with other characters and the dire upshot resulting from this relation. The study found that Paul strove for happiness through the concerted entertainment of body and soul with his beloved people, but he failed because his mother's unusual attachment to him negatively impacted on his building up a normal relation with others. Mother's failure to find happiness in her conjugal life led her to pouring her love into Paul, exploiting him, making him sub-serve her own need and denying him the right to his own independent life. As a result, the son's relation with other women proved a disastrous failure. The women with whom Paul had relation underwent part of the sufferings somehow or other. Finally, Mother's death made him hopeless and left his life in nothingness.
\end{abstract}

Keywords: Body-mind, Happiness, Mother-son, Quest, Relation

\section{Introduction}

David Herbert Lawrence (1885-1930), a short-lived English novelist, poet, playwright and literary critic, was one of the most controversial figures of the twentieth century English literature. His works basically focused on the dehumanizing effects of industrialization and modernity in England. His most widely read novel Sons and Lovers earned him both fame and piercing criticism from readers. This novel shows how the backbreaking toil of a husband named Walter Morel in the process of industrialism dehumanized him and his son Paul Morel, denied fatherly love, aspired to make it up by resorting to his mother's harrowing affection and other women's deviating attachment. The novel delicately narrates how Paul's mother preoccupied him. His wavering between his mother and his beloved manifests his quest for physical pleasure and spiritual happiness.

The happiness of a person lies in the harmonious interplay of his body and mind. The imbalance of one part causes the functional disharmony of the other. A person strives to find both his essential entities - body and mind - operate properly to enjoy happiness in life (Stumpf, 1975). Surely this rhythmic tune of body and mind results from a peaceful relationship with his intimate people. David Herbert Lawrence's Sons and Lovers depicts a family in which conjugal strife left a dreadful impact on the children. In this novel mother-son relation assumed an unusual dimension where the mother showed too much care to her son and the son sacrificed his love and affection for other women at the altar of her happiness. The writer contrived to show the mother's unusual relation with Paul Morel and his futile affairs with other women in this novel. Much study has been done on the mother-son relation and the relational crisis from psychoanalytic and feminist perspective. But this article made a critical analysis of the protagonist Paul Morel and shed light on the crisis between his body and mind and his yawning effort to resolve the problem.

\section{Discussion}

Sons and Lovers starts with a resonant description of a commonplace family named after Mr. Morel, an uncouth collier. Mrs. Morel's rosy dreams that her marriage with an adventurous coal miner would bring happiness in her life proved a mirage immediately after half a year of their conjugal life had elapsed. Disillusioned by Mr. Morel's lack of moral and intellectual footing, Mrs. Morel at last withdraws her affections from her husband, "His wife relentlessly, casting him off and turning to none for love and life but to the children" (84).

After the tragic death of William, Mrs. Morel grappled with Paul and he became her only refuge where she could shelter for survival and redeeming the sigh of un-fulfillment in her life. Her emotional urge is depicted thus:

Mrs. Morel clung now to Paul. He was quiet and now brilliant. But still he stuck to his painting, and still he stuck to his mother. Everything he did was for her. She waited for his coming home in the evening, and then she unburdened herself of all she had pondered or of all that had occurred to her during the day. He sat and listened with his earnestness. The two shared lives. (p.144)

Her excessive care for Paul Morel started shaping his person and as a result, a mother-fixation assumed his character type. Now his company entertained her; his concern for her satisfied her and imperceptible development of unusual filial love made her happy. When they had a tour or journey, they both got overjoyed at each other's company. Her 
exuberant outburst of happiness sounded like they were lovers. Unknowingly he lost control over the rein of his mind and his sole mission was to make her happy. 'Here's a bit of new-mow hay,' he said; then, again, he brought her forgetme-nots, And, again, his heart hurt with love, seeing her hand, used with work, holding the little bunch of flowers he gave her. She was perfectly happy" (p.155). This intimate mother-son relation ate up his potentials of materializing a relationship with any other woman. Thus his relation with both Miriam and Clara Dawes resulted in an absolute failure. By contrast, Ahmed (2012) ruled out the mother-fixation theory and reasoned that mother's unusual treatment of love for Paul resulted from a particular adverse conjugal experience and Paul had to suffer the fatal consequences along with his mother. But Haque (2005) found in mother's shifting from husband to son an air of contemporary social phenomenon, "Women who are not happy with their husbands tend to shift their attention from their husbands to their children. It is common in contemporary society." Whatever the reason of their extreme intimacy might be, Paul failed to come out of the intricacy of this relation.

Up to the end of the novel, we see Mrs. Morel's lasting influence in Paul Morel's life. When he was to establish a relationship with Miriam, mother's influence determined the type of relation he wanted with Miriam. Brian Finney (1990) observed that not only did she invite Paul to occupy the place of her husband but accused Miriam of the same possessive love with which she smothered Paul. Mother's influence shadowed his life. As an artist he received the power of imagination from Miriam and the vibrancy from his mother. "In Contact with Miriam he gained insight; his vision went deeper. From his mother he drew the life-warmth, the strength to produce; "Miriam urged this warmth into intensity like a white light” (p.196). Mother's Omni-presence did not let him develop his individual self. Ironically Mrs. Morel grudged that Miriam would suck her son's soul out and would not let him be a man. 'She is one of those who will want to suck a man's soul out till he had none of his own left,' she said to herself; 'and he is just such a gaby as to let himself be absorbed. She will never let him become a man; she never will.' (p.199)

The recurrence of her cries complaining about Miriam's intrusion upon Paul's relation with his mother was echoed throughout the novel:

She's not like an ordinary Woman, who can leave me my share in him. She wants to absorb him.

She wants to draw him out and absorb him till there is nothing left of him, even for himself. She will never be a man on his feet -she will suck him up. (p.237)

Paul did not seem to pay heed to his mother's grudge. He rushed to Miriam to satisfy his hungry body and mind, but Miriam's religiosity did not allow her to submit her body to Paul. He complained that he was not happy only because his body was dissatisfied. He blamed that it was the soul, not the body that Miriam wanted. When he left Willey Farm, he could do no work as if something were drawing his soul out towards Willey Farm. "He felt that she wanted the soul out of his body, and not him. All his strength and energy she drew into herself through some channel which united." (p.239). Louis L. Martz's comment is here worth noticing: "His bursts of anger and 'hate', his feeling that Miriam is pulling the soul out of his body, are only his own tormented reactions to the agony he feels in being pulled so strongly away from his mother" (Martz 1996). But as the plot develops we notice that it was not Miriam, rather Mrs. Morel herself who sucked Paul's life out.

Both Paul and Miriam loved each other passionately, but Paul was not happy. He thought Miriam's religiosity was the bar to the attainment of the desired felicity from this relationship. Their platonic love incurred a burden of pain he was unable to bear. He was searching for the solution of how to disburden the anguish. Time and again he in his heart blamed Miriam that her hyper-spirituality made him think he was also a spirit. His solid conviction was that only through physicality he would be able to attain the bliss he was aspiring for:

The fact that he might want her as a man wants a woman had in him been suppressed into a shame. When she shrank in her convulsed, coiled torture from the thought of such a thing. . . It was as if she could scarcely stand the shock of physical love, even a passionate kiss, and then he was too shrinking and sensitive to give it. (p.221)

Paul hated Miriam because she, somehow, ruined his ease and naturalness. And he was tormented with a 'feeling of humiliation'. His life turned desperate, sometimes, cruelly disregarding his mother's concern and also misbehaving towards Miriam. Lawrence nicely said, "Recklessness is almost a man's revenge on his women. He feels he is not valued, so he will risk destroying himself to deprive her altogether" (p.235). Paul endeavored to destroy her religious beliefs. He began to question her orthodox belief. He ruthlessly hurt her and cruelly smashed her convictions. He knew very well that her platonic attitude to love rested on puritanical beliefs that imposed a taboo on extramarital physical relation. He reproached Miriam that her eternal and abnormal craving was to be loved. And this love was, of course, spiritual. Miriam was brought up with the Christian orthodox belief that extra-marital relation must be rewarded with severe divine-punishment. The affliction of this belief came as a dividing line in between her spiritual bliss and Paul Morel's physical consummation. On the contrary, he got mad for meeting the demand of the flesh and blood. His despising words sounded like his fretted, tortured soul, moved by resisted passion, kicked off the sorrows and sufferings he was undergoing. His entire attempt here was to be happy by attaining the union of body and soul. Ironically she did not understand what this humiliation insinuated. She thought and thought. Because of her extreme religiosity the relation between them assumed the air of such an abstraction that even her putting arm in his caused him almost torture. "The place where she was touching him ran hot with friction. He was one internecine battle, and he became cruel to her because of it" (p. 214). In an excursion when they were walking together, his blood ran hot with the warm touches of Miriam; but there intimacy was so platonic that he did not know he wanted to crush her on his breast to disburden the anguish he was undergoing. 
Paul's short-lived relation with Clara Dawes occurred to him as a magic spray to heal the suffering for the time being. He apprised her of the frigidity of his relation with Miriam. Clara gave him an insight into woman psychology. From Clara he gathered that though Miriam's soul recoiled from the idea of physical relation, her body yearned for it desperately. The following part of a dialogue between Paul and Clara goes thus:

'How do you know what she is?'

'I do! I know she wants a sort of soul union.'

'But how do you know what she wants?'

'I've been with her for seven years.'

'And you haven't found out the very first thing about her.'

'What's that?'

'That she doesn't want any of your soul communions. That's your own

imagination. She wants you.' (p.339)

Paul Morel now received the drive from Clara Dawes to approach Miriam. But mother-fixation came in the way of his advancement. Millett (1996) opined, "The sexual therapy Clara affords to Paul is meant to be a balm to his virulent oedipal syndrome, but is even more obviously a slave to his ego". D. H. Lawrence interpreted Paul's hindrance to a normal relationship with Miriam:

A good many of the nicest men he knew were like himself, bound in by their own virginity, which they could not break out of. . . . Being the sons of mothers whose husbands had blundered rather brutally through their feminine sanctities, they were themselves too diffident and shy. They could easier deny themselves than incur any reproach from a woman; for a woman was like their mother, and they were full of the sense of the mother. (p.341)

With the utmost effort Paul finally succeeded in consummating his love with Miriam, but it was not a success, rather a complete failure as far as happiness was concerned. Immediately after he had had her, he felt like crying. He had the dull pain in his soul. The thought of death, the after-life seemed to him sweet and consoling. He could hardly bear that she lay to be sacrificed for him because she loved him so much. Though Miriam yielded to the physicality of her relation with Paul, she inwardly suffered the torments which the sense of losing virginity incurred upon her. Her frigid response made him feel guilty of what he had explored. This sexual intercourse cut the remaining bond they were fastened with. Now he lost his footing - the belief that love materialized would provide him with ecstasy. A reader would feel about his increasing disappointment and bitterness that it tore him apart physically, exhausted him and shattered him. His final recourse to bodily relation for happiness turned illusory. Spilka (1970) saw the matter through the lens of Paul and gave an interpretation of this split: "Thus the chief 'split' between Paul and Miriam comes from the abstract nature of their love, and not from the mother's hold upon the young man's soul. And the final responsibility for this split belongs with Miriam”. But Martz (1996) strongly protests this view and presents Miriam with positive light. He holds, "Miriam does not bear the slightest blame for the failure of this relationship: she is like a "pomegranate for richness', like the bride in the Song of Solomon, she combines a pure beauty of sensuous appeal with all the soul that Paul the artist needs for his further development". But our subtle observation found that mother's obsessive intrusion into his personal affair left a divider between the harmony of his body and soul. Her inane shadowing Paul Morel's hanging out with Miriam made his life restless. Her reproach reached such a climactic point that he was alleged to have forsaken his mother because she became aged and her beauty was gone which was why Paul was chasing after a sucking girl. In reality his obsequious passion for mother was so persistent that his indulgent body always succumbed to his soul's return to his mother's onerous grip. The velocity of mother's magnetic pull tore him apart, bewildered him and numbed his whole existence. He felt cruel towards Miriam at the thought of his mother's suffering. When he returned from Miriam, "His mother saw on him the marks of some agony, and she said nothing. But he had to make her talk to him. Then she was angry with him for going so far with Miriam” (p. 238).

Paul reasoned out why he was dissatisfied even when he experienced long-cherished physical union with Miriam. It was, he concluded, Miriam's lack of spontaneity that bred a fatal gulf between their further close relations. Paul's eternal journey towards the fulfillment of the demands of body and mind continued. He turned to boisterous and buoyant Clara whose intimacy would, he anticipated, mitigate his agony. Paul Morel was the proto-type of Mrs. Morel's life. Denied the warmth of love (spiritual) by her husband, Mrs. Morel clutched at her sons; likewise, Paul Morel, failing to gain vibrant love (physical) from Miriam, jumped at the relation with Clara. Their swap fomented the unrest of their own life. Now Paul entered a sexual relationship with Clara. A pernicious tension pervaded this relation. The lightness of his being - switching from Mother to Miriam to Clara for happiness - became unbearable to him. Clara's passionate touch and her quick kisses made him feel as if she were helpless, almost a burden to him, and irritated him desperately (p. 432). His insatiable desire for mental peace found no resort to Clara's specious physical submission. He confessed to Clara, "If I start to make love to you,' he said, 'I just go like a leaf down the wind" (p.442). Clara's robust performance failed to place him on a stronghold where he would feel safe and would not tremble at the thought of being carried away like a leaf by the wind. Finally Paul understood that it was his mother who ate away at his self day by day. He dragged his body to Clara but his soul remained behind at his mother. His struggle with his split existence grieved Clara. Clara blamed his non-existent self, "but you've never come near to me. You can't come out of yourself, you 
can't" (p.441). Paul admitted to her that it was the surviving influence of his mother that impeded his normal relation with any woman. He sighed, "I don't know. I shall hardly go for long, while there's my mother" (p.428). He ended up not merely berating his mother for her imposing caring, he also attempted to set himself free from her clutches, but failed. Keith Sagar (1970) vividly depicts Paul's helplessness: "Unless he can learn to live without daily reference to her and dependence on her, no complete relation with another woman will be possible for him, nor will he be able to survive his mother's death".

Mother and Son were like the two feet of a compass - we find this compass imagery in John Donne's poem, 'A Valediction: forbidding mourning'-Mother being the fixed foot in the centre and, Paul the other foot that moves round her. The firmness of Mother's unfathomable love drew Paul, the moving feet, near to her after he finished moving around. The poem runs: "Thy firmness makes my circle just, / And makes me end, where I begun" (Donne, 1896. Lines: 35-36). We notice the same imagery in Sons and Lovers, "His life wanted to free itself of her. It was like a circle where life turned back on itself, and got no farther." (p.420). He turned back to his mother because his mother's is the strongest tie in his life. When he thought about his relation with Miriam, she shrank away. His feel for her sounded obscure. Nobody else except for Mother mattered. His mother is the pivot and center of his life. Everybody else became cloudy and nonexistent to him. But Mother gave a different interpretation of his unsuccessful relation. She held that Paul had not found the right woman for his life which was why he was suffering. A small part of their dialogue pinpointed the situation:

'You haven't met the right woman.'

'I never shall meet the right woman while you live,' he said. (p.427)

Paul's relations with both Miriam and Clara culminated in an absolute failure. He was groping for hold in the mountainous waves of the ocean of nothingness. And Mrs. Morel's tragic death exacerbated his sufferings. To him, her departure felt tantamount to the loss of his own self. At night he repeatedly cried out for his mother, "My love - my love - oh, my love!" (p.484). Who-ever he wanted to hold slipped away. In his mother he had found the repose during his crisis moments. Now she was gone. His juvenile dreams 'fell apart'. With the dying of his mother, his sexuality began to equate itself more and more with actual death. Lawrence's workmanship revealed the undercurrent of Paul, "Paul felt crumpled up and lonely. His mother had really supported his life. He had loved her; they two had, in fact, faced the world together. Now she was gone, and forever behind him was the gap in life. ..."(p.495).

His mental state grew grimmer as if he were heading for the void through the meaninglessness of life. "The people hurrying along the streets offered no obstruction to the void in which he found himself." (p.510). Tears misted his eyes. The phantom of his dead mother stood in between him and the life to pass. The panoramic view around appeared to him like piercing torture. It was all nothingness; even his non-substantial existence was also a mere nothingness. The life he passed and the life to come was a brutal nothingness. The deadly form of his life struggled for survival, but the wings of hope flapped down the abyss of nothingness. D. H. Lawrence dramatically depicted his deadening disillusionment of life: "So the weeks went on. Always alone, his soul oscillated, first on the side of death, then on the side of life, doggedly. The real agony was that he had nowhere to go, nothing to do, nothing to say, and was nothing himself" (p.501). But Weiss (1970) sees her death positively and points out that nobody can raise question about the moral basis of the mother-son relation because Mrs. Morel was removed from the scene when there developed some imperceptible weaknesses for each other. Mrs. Morel's death, comments Weiss, came as a relief to Paul's stalemate like the diabolical fulfillment of an oracle (Weiss, 1970). At the heart of Paul's anguish lied an unconscious awareness of the secondary advantage to be gained from her death — she will be preserved to him. Niazi (2013) holds, "Paul feels liberated by his mother's death and yet it seems to relegate him into a deathlike state of horrifying nothingness_-an unreality." One of the great wishes was that she would remain young and uncorrupted, virginal. Her death completed the transformation. She became the fulfillment of his wish: "She lay like a maiden asleep. With his candle in his hand, he bent over her. . . He bent and kissed her passionately" (p.485).

\section{Conclusion}

The aspiration for happiness drove Paul for action. Mrs. Morel's striving for love from her son led to the destruction of her own son's happiness along with that of other characters closely associated with Paul. Her imposing character contributed to the nothingness in Paul's life and his stale relations with other women. Paul Morel never enjoyed the spontaneity of life. He switched from his mother to Miriam to Clara, but failed to attain the divine bliss he had expected. Finally his mother's illness and inability to hold him anymore aggravated his crisis. He hastened the death of his mother with morphine to set her free from the sufferings a part of which he was also undergoing. Now the person who pulled him from behind passed away, but still he failed to make a successful relation with Miriam because it was his mother that had given him the drive to both love and hate. He could not even wait in the forlorn hope that he would come across some happy moments that would sweep away the debris of nightmares of past life and show him some way out to enjoy a future life full of rest and happiness. 


\section{References}

Ahmed, Sofe (2012). Sigmund Freud's psychoanalytic theory Oedipus complex: A critical study with reference to D.H. Lawrence's "Sons and Lovers". Internal journal of English and literature: vol. 3(3). pp: 6070.http://www.academicjournals.org/ijel. DOI:10.5897/IJEL11.137

Denial A. Weiss (1970). "The Mother in the Mind". Twentieth Century Interpretations of Son and Lovers. Ed. Judith Farr. New Jersey: Prentice Hall Press. pp. 28-41.

Donne, John (1896). Poems of John Donne. vol I. Ed. E. K. Chambers. London: Lawrence \& Bullen. pp. 51-52

Finney, Brian (1990). D. H. Lawrence: Sons and Lovers. Ed. Bryan Loughry. England: Clays Ltd.

Haque, Salma (2005). Mrs. Gertrude Morel and Her Realization in D.H. Lawrence's Sons and Lovers: A Study.Pakistan Journal of Social Sciences, 3: 712-714.

Lawrence, D.H (2006). Sons and Lovers. Dhaka: Mim Printers.

L. Martz, Louis (2006). “A Protrait of Miriam: A Study in the Design of Sons and Lovers." New Casebooks Sonsand Lovers. Ed. Rick Rylance. London: Macmillan Press Ltd. 49-73.

Millett, Kate (1996). "Sexual Politics in Sons and Lovers." New Casebooks Sons and Lovers. Ed. Rick Rylance. London: Macmillan Press Ltd. pp.49-73.

Niazi, Nozar (2013). A Stylistic Analysis of D. H. Lawrence's 'Sons and Lovers': International Journal of Applied Linguistics and English Literature. URL: http://dx.doi.org/10.7575/aiac.ijalel.v.2.p4.118

Sagar, Keith (1970). "Sons and Lovers". Twentieth Century Interpretations of Son and Lovers. Ed. Judith Farr. New Jersey: Prentice Hall Press. pp.42-50.

Spilka, Mark (1970). "Sons and Lovers". Twentieth Century Interpretations of Son and Lovers. Ed. Judith Farr. New Jersey: Prentice Hall Press.

Stumpf, Samuel Enoch (1975). SOCRATES TO SARTRE: A History of Philosophy. New York: McGraw-Hill Book Company. 